\title{
Pengaruh Penyuluhan Terhadap Pengetahuan Demam Berdarah Warga Desa Potronayan, Nogosari, Boyolali
}

${ }^{1}$ *Hidayah Karuniawati, ${ }^{1}$ Maryati, ${ }^{1}$ Gunawan Setiyadi, ${ }^{1}$ Suprapto, ${ }^{1}$ Andika Permana, ${ }^{1}$ Septi Fatmawati,

${ }^{1}$ Ashari Wahyu Budi Aji, ${ }^{1}$ Hevi Mifta Kumalasari, ${ }^{1}$ Yunika Isnanda Pratiwi, ${ }^{1}$ Sakinatul Hayati

${ }^{1}$ Fakultas Farmasi Universitas Muhammadiyah Surakarta

*Penulis korespondensi, email: hk170@ums.ac.id

(Received: 2 July 2020/Accepted: 5 July 2020/Published: 7 July 2020)

\begin{abstract}
Abstrak
Secara Nasional, kasus Demam Berdarah Dengue terus meningkat dikalangan masyarakat. Kasus terbanyak ada di wilayah Jawa Timur, Jawa Tengah, Nusa Tenggara Timur, dan Kupang. Pengetahuan masyarakat mengenai demam berdarah terutama cara pencegahan dan pengobatan belum sepenuhnya mengerti sehingga diperlukan pengabdian untuk membantu masyarakat dalam mencegah dan memberantas kasus demam berdarah dengan memberikan sosialisasi penyuluhan. Kegiatan penyuluhan yang dilakukan adalah dengan memberikan materi kesehatan berupa upaya pencegahan, menjaga kebersihan lingkungan dan penanganan pertama yang dilakukan jika terkena Demam berdarah. Kegiatan pengabdian masyarakat diikuti 43 peserta. Sebelum dan sesudah pemberian materi tentang demam berdarah, peserta diberi soal sebagai pretest dan post-test. Hasil analisis statistik menunjukkan adanya pengaruh peningkatan pengetahuan yang signifikan sebelum dan setelah penyuluhan dengan nilai $P$ 0,005.
\end{abstract}

Kata Kunci : demam berdarah, penyuluhan, pengetahuan

\begin{abstract}
Nationally, the case of Dengue Fever continues to increase among the people. The most cases are in East Java, Central Java, East Nusa Tenggara and Kupang. Knowledge about dengue fever, especially how to prevent and treat it, is not fully understood, so that community services is needed to help the community in preventing and eradicating dengue cases by providing information dissemination. Counselling activities carried out are by providing health material in the form of prevention efforts, maintaining environmental cleanliness and medical treatment carried out if exposed to dengue fever. The community service activity was attended by 43 participants. Before and after giving materials about dengue fever, participants were given questions as a pre-test and post-test. Statistical analysis showed that there was a significant increase in knowledge before and after health education with $p$ value 0.005.
\end{abstract}

Keywords : dengue fever, health education, knowledge

\section{Pendahuluan}

Secara Nasional, kasus Demam Berdarah Dengue (DBD) terus meningkat dikalangan masyarakat. Berdasarkan data yang dirilis oleh Kementerian Kesehatan, jumlah kasus DBD per 29 Januari 2019 mencapai 13.683 dengan jumlah pasien yang meninggal dunia sebanyak 133 jiwa. Jumlah tersebut terus meningkat ditandai dengan jumlah kasus DBD hingga 3 Februari 2019 mencapai 16.692 kasus dan 169 diantaranya meninggal. Kasus terbanyak ada di wilayah Jawa Timur, Jawa Tengah, NTT dan Kupang. Demam berdarah menyerang semua umur baik anak anak maupun orang dewasa. 
Demam Berdarah Dengue (DBD) adalah penyakit menular yang disebabkan oleh virus Dengue dan ditularkan oleh gigitan nyamuk Aedes Aegypti. Nyamuk Aedes Aegypti tersebar luas di seluruh daerah baik perkotaan maupun pedesaan (Hasyim, 2013). Menurut Kementerian Kesehatan Republik Indonesia, 2013 terdapat empat tipe virus yang dikenal, yakni DEN-1, DEN2, DEN-3, dan DEN-4. Ke empat tipe virus ini telah ditemukan di berbagai wilayah Indonesia. Hasil penelitian di Indonesia menunjukkan bahwa Dengue-3 merupakan virus yang dominan terhadap penyebab DBD dengan gejala paling berat, disusul oleh Dengue-2, Dengue-1 dan Dengue-4.

Pada musim hujan populasi nyamuk Aedes aegypti akan meningkat karena telur - telur yang tadinya belum sempat menetas akan menetas ketika tempat perkembangbiakannya (TPA bukan keperluan sehari - hari dan alamiah) mulai terisi air hujan. Kondisi tersebut akan meningkatkan populasi nyamuk sehingga dapat menyebabkan peningkatan penularan penyakit Dengue (Kementerian Kesehatan Republik Indonesia, 2013).

Kecamatan Nogosari terdiri dari 13 desa dengan luas wilayah 5.508,43 Ha dan berpenduduk 66,928 jiwa yang terdiri dari 33,729 laki-laki dan 33,199 penduduk perempuan sehingga mempunyai kepadatan penduduk sebesar 1,215 jiwa / Km2, sedangkan jumlah kepala keluarga sebanyak 22,483 KK. (Kecamatan Nogosari Dalam Angka, 2018). Desa Potronayan merupakan desa di Kecamatan Nogosari, Boyolali, Jawa Tengah. Desa Potronayan memiliki batas wilayah sebelah utara dengan Desa Guli, sebelah selatan Kecamatan Ngemplak, sebelah barat desa Kenteng dan sebelah timur Kecamatan Ngemplak terdiri dari tiga dusun. Desa ini memiliki produk unggulan dibidang tahu dan mebel dimana Pemerintah Desa bersama warga merintis Badan Usaha Milik Desa yang bergerak di bidang industri mebel. Warga desa mengandalkan Pertanian sebagai pendapatan utama. Dengan pekerjaan warga yang sering berada diluar rumah baik disawah maupun di tempat usaha memungkinkan warga untuk terkena Demam Berdarah karena kurangnya concern terhadap lingkungan yang menjadi tempat berkembangbiak nyamuk.

Pencegahan demam berdarah merupakan tanggungjawab bersama seluruh elemen masyarakat, dengan salah satu elemen terkecil adalah keluarga (Dewi, 2015). Pencegahan penyakit demam berdarah yang paling efektif adalah dengan melibatkan peran serta masyarakat melalui perubahan perilaku yang berhubungan dengan pencegahan penyakit demam berdarah (Natalia, 2010). Penelitian Dewi (2015) menyatakan bahwa faktor pengalaman sakit DBD, pengetahuan, sikap, pengalaman mendapat penyuluhan, dan dukungan petugas kesehatan berhubungan dengan Praktik Pemberantasan Sarang Nyamuk Demam Berdarah Dengue (PSN DBD) Keluarga di Kelurahan Mulyoharjo Kecamatan Jepara Kabupaten Jepara. Dalam penelitian Azizah,dkk (2017) juga menyebutkan bahwa faktor peraturan atau kebijakan yang ada, dukungan keluarga, pengetahuan dan dukungan tokoh masyarakat berhubungan dengan perilaku (PSN 3M Plus) sebagai upaya pencegahan DBD pada masyarakat Kelurahan Sendang mulyo Semarang.

Jumlah penderita diperkirakan akan terus meningkat karena pengaruh musim penghujan. Selain itu masalah utama yang terjadi dikalangan masyarakat adalah kurangnya pengetahuan bagaimana melakukan pecegahan terhadap penyakit demam berdarah. Pengetahuan masyarakat mengenai demam berdarah terutama cara pencegahan dan pengobatan belum sepenuhnya baik sehingga pengabdian masyarakt sangat diperlukan untuk membantu masyarakat dalam mencegah dan memberantas kasus demam berdarah dengan memberikan sosialisasi penyuluhan. Kegiatan penyuluhan yang dilakukan adalah dengan memberikan materi kesehatan berupa upaya pencegahan, menjaga kebersihan lingkungan dan penanganan medis yang dilakukan jika terkena DB.

\section{Metode}

Pengabdian ini dilakukan dengan metode quasi-experimental design yaitu metode yang dilakukan dengan memberikan intervensi kepada subyek tanpa memodifikasi atau mengendalikan variabel-variabel seperti usia dan tingkat Pendidikan yang dapat mempengaruhi pengetahuan 
subyek. Untuk mengetahui efek atau pengaruh pemberian informasi tentang demam berdarah melalui penyuluhan, dilakukan dengan membandingkan pengaruh sebelum dan sesudah perlakuan dengan pengisian kuisioner oleh responden. Responden mengisi kuisioner sebelum dilakukan penyuluhan. Pada hari yang sama kuisioner dikumpulkan dan selanjutnya disampaikan materi presentasi. Kemudian dilanjutkan dengan mengisi kuisioner yang pertanyaanya sama dengan kuisioner sebelum penyampaian penyuluhan. Peneliti kemudian mengumpulkan data tertulis. Dilanjutkan diskusi dan tanya jawab dengan peserta supaya bisa lebih memahamkan peserta tentang topik penyuluhan dan mengeksplorasi sampai sejauh mana peserta menerima informasi tentang topik penyuluhan.

Data dianalisis secara deskriptif dan analitik. Analisis secara deskriptif dilakukan untuk mengetahui prosentasi responden yang meliputi prosentase umur, jenis kelamin, tingkat pendidikan dan skor responden. Soal pretest dan post-test terdiri dari 10 pertanyaan yang terkait dengan demam berdarah. Jawaban yang benar mendapatkan nilai 1 sehingga total nilai berjumlah 10. Semua jawaban benar kemudian dirata - rata:

$$
\text { Rata }- \text { rata jawaban benar }=\frac{\text { jumlah jawaban benar }}{\text { jumlah soal }} \times 100 \%
$$

Analisis secara analitik digunakan untuk menilai pengaruh pemberian penyuluhan terhadap peningkatan pengetahun masyarakat tentang demam berdarah dengan uji t berpasangan.

Tabel 1. Rancangan Pengabdian Perlakuan

\begin{tabular}{lll}
\hline \multicolumn{1}{c}{$\mathbf{1}$} & \multicolumn{1}{c}{$\mathbf{X}$} & \multicolumn{1}{c}{$\mathbf{2}$} \\
\hline $\begin{array}{l}\text { Pre-test } \\
\text { (pengumpulan data dengan } \\
\text { menggunakan kuisioner) }\end{array}$ & $\begin{array}{l}\text { Penyampaian informasi } \\
\text { (informasi yang dilakukan yaitu } \\
\text { dengan penyuluhan) }\end{array}$ & $\begin{array}{l}\text { Post-test } \\
\text { (pengumpulan data dengan } \\
\text { menggunakan kuisioner yang } \\
\text { sama) }\end{array}$ \\
\hline
\end{tabular}

\section{Hasil dan Pembahasan}

Kegiatan pengabdian masyarakat yang berupa penyuluhan kesehatan dilaksanakan pada hari Minggu, 15 Desember 2019 bertempat di Balai Desa Potronayan, Nogosari. Kegiatan penyuluhan ini merupakan bagian dari kegiatan Pengabdian masyarakat yang dilakukan oleh beberapa dosen dan mahasiswa fakultas Farmasi UMS dengan tema besar "Sehat Bersama Masyarakat Cerdas Obat". Kegiatan pengabdian masyarakat terdiri dari pengobatan massal, pemberian obat gratis, pemberian informasi obat atau konseling tentang obat, dan penyuluhan kesehatan yang berlangsung dari jam 07.00-14.00.

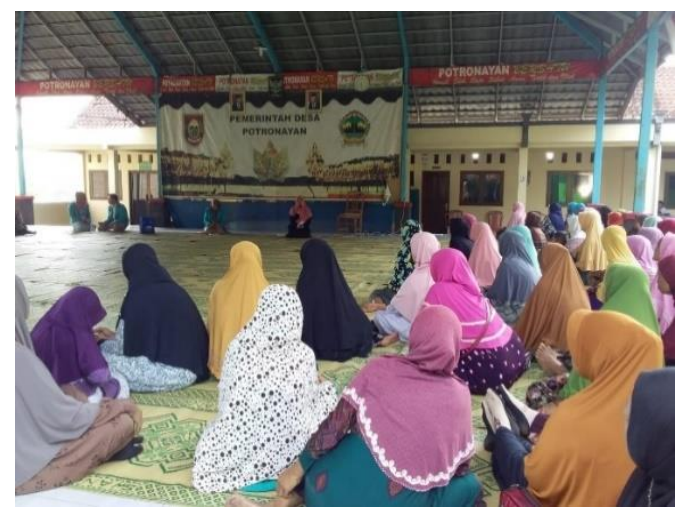

Gambar 1. Pelaksanaan penyuluhan kesehatan di Balai Desa Potronayan, Nogosari 
Peserta yang mengikuti penyuluhan sebanyak 43 orang. Peserta penyuluhan mendapatkan leaflet yang berkaitan dengan materi penyuluhan. Selain pemberian leaflet, materi juga disampaikan melalui presentasi dengan bantuan power point. Setelah penyampaian materi selanjutnya dilakukan sesi tanya jawab. Selanjutnya acara ditutup dengan pembagian doorprize kepada peserta yang telah mengajukan pertanyaan maupun yang berpartisipasi ketika penyuluhan berlangsung. Sebelum dan setelah penyampaian materi, peserta mendapatkan soal untuk dikerjakan secara individu yang digunakan untuk mengukur keberhasilan tersampaikannya materi atau mengetahui pengaruh penyuluhan terhadap pengetahuan DBD warga masyarakat desa Potronayan. Dari 43 peserta yang mengikuti penyuluhan sebanyak 26 peserta mengisi kuesioner lengkap, baik pretes maupun post test. Sebanyak 17 peserta tidak dapat dianalisis pengaruh penyuluhan terhadap peningkatan pengetahuan terhadap DBD karena beberapa orang sudah tua, tidak bisa baca tulis, dan sebagian mengerjakan hanya pretest atau post test saja. Karakteristik peserta dapat dilihat pada gambar 2 dan tabel 2. Sedangkan hasil uji statistik pengaruh penyuluhan terhadap pengetahuan DBD warga desa Potronayan ditampilkan pada tabel 3.
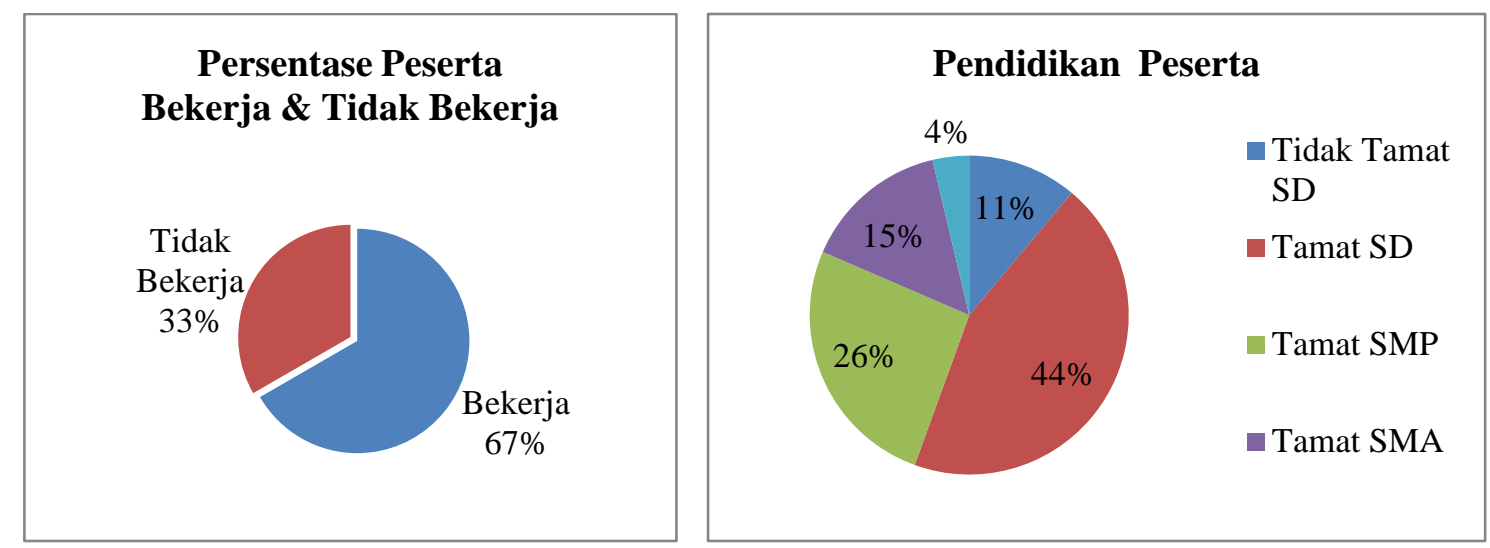

Gambar 2. Karakteristik peserta penyuluhan di desa Potronayan

Tabel 2. Profil peserta penyuluhan serta hasil pretest dan post test

\begin{tabular}{|c|c|c|c|c|c|c|c|}
\hline $\begin{array}{l}\text { No. peserta } \\
\text { penyuluhan }\end{array}$ & $\begin{array}{c}\text { Umur } \\
\text { (thn) }\end{array}$ & $\begin{array}{c}\text { Jenis } \\
\text { Kelamin }\end{array}$ & Alamat & Pekerjaan & Pendidikan & Pretest & Post test \\
\hline 1 & 45 & Perempuan & Rejosari & Wiraswasta & Tamat SD & 7 & 9 \\
\hline 2 & 53 & Perempuan & Sempol & Petani & Tamat SD & 10 & 10 \\
\hline 3 & 38 & Perempuan & Sempol & Tidak Bekerja & Tamat SMP & 10 & 10 \\
\hline 4 & 46 & Perempuan & Sempol & Petani & Tidak Tamat SD & 8 & 9 \\
\hline 5 & 50 & Perempuan & Sanggrahan & Wiraswasta & Tamat SD & 10 & 10 \\
\hline 6 & 72 & Perempuan & Sempol & Petani & Tamat SD & 10 & 10 \\
\hline 7 & 44 & Perempuan & Sempol & Tidak Bekerja & Tamat SMP & 10 & 10 \\
\hline 8 & 55 & Perempuan & Sempol & Petani & Tamat SD & 10 & 10 \\
\hline 9 & 59 & Perempuan & Potronayan & Tidak Bekerja & Tamat SMA & 9 & 10 \\
\hline 10 & 73 & Perempuan & Sempol & Tidak Bekerja & Tidak Tamat SD & 8 & 8 \\
\hline 11 & 62 & Perempuan & Potronayan & Tidak Bekerja & Tamat SMA & 10 & 10 \\
\hline 12 & 49 & Perempuan & Potronayan & Wiraswasta & Tamat SD & 10 & 10 \\
\hline 13 & 48 & Perempuan & Potronayan & Wiraswasta & Tamat SMP & 10 & 10 \\
\hline 14 & 56 & Perempuan & Sempol & Wiraswasta & Tamat SD & 10 & 10 \\
\hline 15 & 55 & Perempuan & Sempol & Wiraswasta & Tamat SD & 10 & 10 \\
\hline 16 & 45 & Perempuan & Pilangsari & Wiraswasta & Tamat SMP & 10 & 10 \\
\hline 17 & 38 & Perempuan & Rejosari & Tidak Bekerja & $\mathrm{S} 1$ & 10 & 10 \\
\hline 18 & 60 & Perempuan & Ngemplak & Wiraswasta & Tamat SMP & 8 & 10 \\
\hline 19 & 53 & Perempuan & Sempol & Wiraswasta & Tamat SMA & 10 & 10 \\
\hline 20 & 49 & Perempuan & Potronayan & Wiraswasta & Tamat SMA & 9 & 10 \\
\hline
\end{tabular}




\begin{tabular}{|c|c|c|c|c|c|c|}
\hline 53 & Perempuan & Sempol & Petani & Tamat SD & 8 & 9 \\
\hline 60 & Perempuan & Jembrangan & Tidak Bekerja & Tidak Tamat SD & 7 & 7 \\
\hline 50 & Perempuan & Sempol & Petani & Tamat SD & 9 & 10 \\
\hline 52 & Perempuan & Potronayan & Wiraswasta & Tamat SD & 10 & 10 \\
\hline 50 & Perempuan & Asem Growong & Wiraswasta & Tamat SMP & 10 & 10 \\
\hline 39 & Perempuan & Pilangsari & Tidak Bekerja & Tamat SMP & 8 & 9 \\
\hline
\end{tabular}

Tabel 3. Hasil uji t berpasangan pengaruh penyuluhan terhadap pengetahuan DBD warga desa Potronayan

\begin{tabular}{lccc}
\hline & n & Rerata \pm s.b & $\boldsymbol{P}$ \\
\hline Pengetahuan sebelum penyuluhan & 26 & $8,93 \pm 1,0$ & 0,005 \\
Pengetahuan setelah penyuluhan & 26 & $9,3 \pm 0,7$ & \\
\hline
\end{tabular}

Semua peserta yang mengisi kuesioner berjenis kelamin wanita, $67 \%$ bekerja, dengan mayoritas pekerjaan peserta adalah sebagai wiraswasta dan petani. Empat puluh empat persen peserta mempunyai latar belakang pendidikan tamat sekolah dasar seperti yang tercantum dalam gambar 2 dan tabel 2. Berdasarkan hasil statistik, menunjukkan bahwa ada pengaruh penyuluhan yang signifikan secara statistik terhadap pengetahuan masyarakat mengenai demam berdarah. Terjadi peningkatan pengetahuan masyarakat setelah diberikan penyuluhan, dan pengetahuan masyarakt tentang demam berdarah lebih baik dibandingkan dengan sebelum diberi penyuluhan dengan nilai $p 0,005$ seperti yang tercantum dalam tabel 3 .

Kegiatan pengabdian masyarakat yang berupa penyuluhan ini dan dengan peningkatan pengetahuan dan pemahaman masyarakat khususnya desa Potronayan setelah diberikan materi penyuluhan mengenai penyakit demam berdarah yang berhubungan dengan cara pencegahan penyakit demam berdarah yang tepat dan cara pengobatan yang tepat, diharapkan peserta dapat mempraktekkan pengetahuan yang sudah didapat sehingga terhindar dari penyakit demam berdarah.

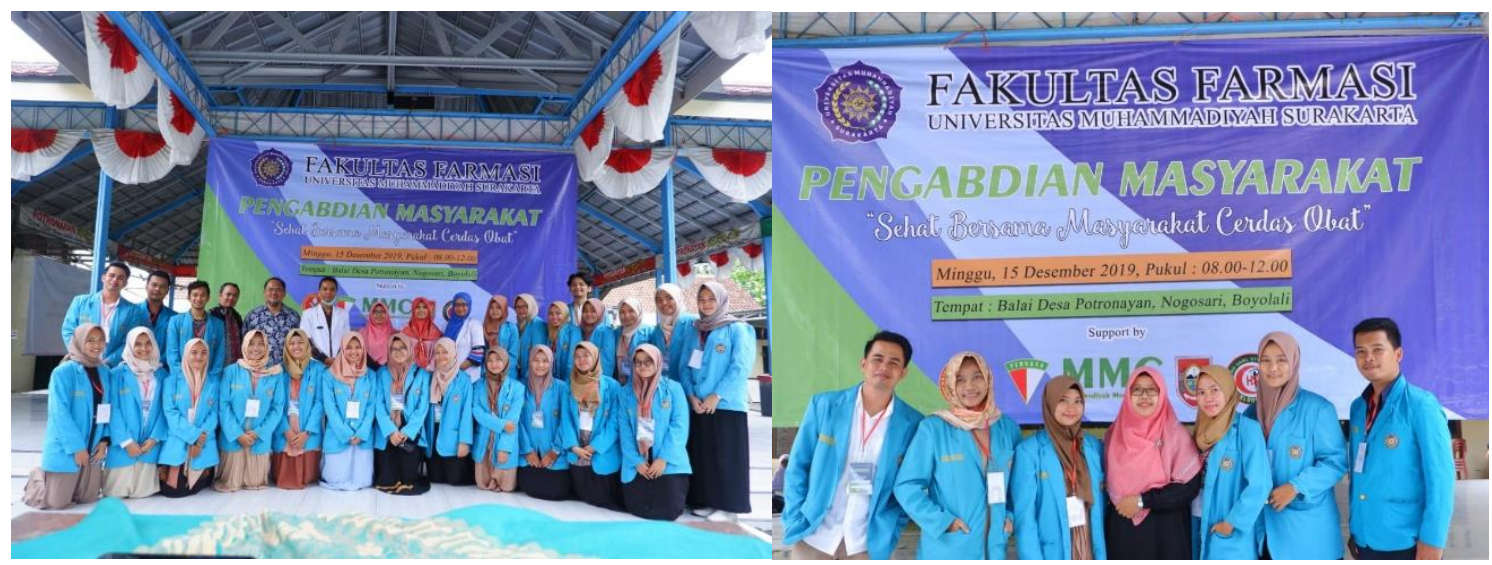

Gambar 3. Foto bersama dosen dan mahasiswa pemateri penyuluhan

\section{Simpulan}

Penyuluhan kesehatan tentang Demam Berdarah di Desa Potronayan kecamatan Nogosari memiliki pengaruh terhadap peningkatan pengetahuan masyarakat mengenai penyakit demam berdarah. Saran yang dapat dilakukan adalah perlu adanya pembinaan rutin sebagai tindak lanjut 
kegiatan pengabdian masyarakat ini dilihat dari antusiasme peserta dan ketertarikan untuk selalu menjaga kebersihan dan tatalaksana pencegahan penyakit Demam Berdarah.

\section{Persantunan}

Penulis mengucapkan terimakasih kepada Fakultas Farmasi Universitas Muhammadiyah Surakarta (UMS), Lembaga Penelitian dan Pengabdian kepada Masyarakat (LPPM) UMS, Muhammadiyah Medical Center (MMC), dr.Fajri Azizah Raudlatul Jannah dan dr. Timotius Dwi Cahyo Roso, dr. Sri Sumiyati Sp.Rad (Klinik Habil Syifa Medika), Pemuda Muhammadiyah Ranting Desa Potronayan, Pengurus Ranting Muhammadiyah Potronayan, Bapak kepala desa Potronayan, dan semua peserta yang tidak bisa disebutkan satu persatu atas bantuan dan perijinan serta partisipasinya sehingga kegiatan pengabdian masyarakat berjalan dengan lancar.

\section{Referensi}

Badan Pusat Statistik. (2018). Kecamatan Nogosari Dalam Angka. Boyolali: BPS Kabupaten Boyolali

Depkes RI. (2010). Data Kasus DBD per Bulan di Indonesia Tahun 2010, 2009 dan 2008. Jakarta: Depkes RI.

Dewi, N.P. (2015). Faktor-Faktor Yang Berhubungan Dengan Praktik Pemberantasan Sarang Nyamuk Demam Berdarah Dengue (PSN DBD) Keluarga Di Kelurahan Mulyoharjo Kecamatan Jepara Kabupaten Jepara. Skripsi Jurusan Ilmu Kesehatan Masyarakat. Fakultas Ilmu Keolahragaan. Universitas Negeri Semarang https://journal.unnes.ac.id

Hasyim, Deddy Maulana. (2013). Faktor - Faktor Yang Berhubungan Dengan Tindakan Pemberantasan Sarang Nyamuk Demam Berdarah Dengue (PSN DBD). Jurnal Kesehatan, Volume IV, Nomor 2.

Kementerian Kesehatan Republik Indonesia. (2013). Pedoman Pengendalian Demam Berdarah Dengue Di Indonesia. Jakarta: Kementerian Kesehatan Republik Indonesia.

Natalia, R. (2010). Pengaruh Faktor Pemudah, Pendukung Dan Pendorong Terhadap Tindakan Kepala Keluarga Dalam Pencegahan Penyakit Malaria Di Desa Kinangkong Kecamatan Lau Baleng Kabupaten Karo Tahun 2010. Skripsi Fakultas Kesehatan Masyarakat. Universitas Sumatera Utara https://www.researchgate.net

www.wikipedia.org, [Diakses pada 10 Desember 2019]

\section{(c) (i) $\Theta$}

(c) 2017 by the authors. Submitted for possible open access publication under the terms and conditions of the Creative Commons Attribution (CC-BY-NC-ND) license (http://creativecommons.org/licenses/by/4.0/). 